\title{
Anti-tuberculosis drugs decrease viability and stimulate the expression of chondrocyte marker genes in human nucleus pulposus cells
}

\author{
TOMASZ P. LEHMANN ${ }^{1}$, MACIEJ GŁOWACKI ${ }^{2}$, EWA MISTERSKA $^{2}$, MICHAŁ WALCZAK $^{2}$, \\ PAWEŁ P. JAGODZIŃSKI ${ }^{1}$ and JAKUB GŁOWACKI ${ }^{3}$ \\ ${ }^{1}$ Department of Biochemistry and Molecular Biology, Poznań University of Medical Sciences, Poznań 60-781; \\ ${ }^{2}$ Department of Pediatric Orthopaedics and Traumatology; ${ }^{3}$ SSG of Paediatric Orthopaedics and Traumatology, Department \\ of Paediatric Orthopaedics and Traumatology, Poznań University of Medical Sciences, Poznań 61-545, Poland
}

Received March 16, 2013; Accepted October 1, 2013

DOI: $10.3892 / \mathrm{mmr} .2013 .1767$

\begin{abstract}
Isoniazid (INH), rifampicin (RIF), ethambutol $(\mathrm{ETH})$ and pyrazinamide (PYR) are first-line drugs used in anti-tuberculosis (TB) therapy. However, no studies have been conducted concerning the effect of anti-TB drugs on the cells of the intervertebral discs (IVDs), the predominant location of the osteoarticular form of TB (OATB). Cells from the nucleus pulposus (NP), which are located in the center of the IVDs, were obtained from 12 adolescent patients who underwent surgery due to idiopathic scoliosis. The NP cells were incubated for $24 \mathrm{~h}$ with transforming growth factor $\beta 1$ (TGF- $\beta 1$ ) and each anti-TB drug (INH, RIF, ETH and PYR), separately. Incubation with $2.5 \mathrm{ng} / \mathrm{ml} \mathrm{TGF}-\beta 1$ resulted in an $80 \%$ decrease in ACAN mRNA levels; while $5 \mu \mathrm{g} / \mathrm{ml} \mathrm{INH}$ led to a 2.3-fold increase in $C O L 2 A 1$ and a 2.9-fold increase in $A C A N$ mRNA levels. Treatment with $10 \mu \mathrm{g} / \mathrm{ml}$ RIF initiated a 2.2-fold increase in COL1A1 mRNA levels and $5 \mu \mathrm{g} / \mathrm{ml}$ PYR resulted in an 8-fold increase in SOX 9 mRNA levels. Following $192 \mathrm{~h}$ of treatment with INH and RIF, NP cell viability was diminished; however, no drugs modified the concentrations of glycosaminoglycans (GAGs). This study aimed to determine the effect of anti-TB drugs on the expression of chondrocyte marker genes in human IVD cells. Anti-TB drugs increased the expression of chondrocyte marker genes and diminished the viability of IVD cells. This study demonstrated that in addition to the common side effects of anti-TB drugs, these drugs also have an effect on IVD cells.
\end{abstract}

Correspondence to: Dr Tomasz Lehmann, Department of Biochemistry and Molecular Biology, Poznań University of Medical Sciences, ul. Święcickiego 6, Poznań 60-781, Poland

E-mail: tlehmann@ump.edu.pl

Key words: spine tuberculosis, anti-tuberculosis drugs, nucleus pulposus, intervertebral disc

\section{Introduction}

Successful chemotherapy of pulmonary and extrapulmonary tuberculosis (TB) requires the prolonged administration of at least three anti-TB drugs (1). Prolonged drug therapy is required to eliminate persistent bacilli, which are small populations of metabolically inactive microorganisms. The recommended standard treatment for adult respiratory TB is a regimen of isoniazid (INH), rifampicin (RIF) and pyrazinamide (PYR) for two months, followed by four months of INH and RIF. Ethambutol (ETH) and streptomycin are also commonly added to this regimen (1).

Tuberculosis is one of the most common causes of mortality from curable infectious diseases. The World Health Organization (WHO) estimated that the incidence of TB was $0.13 \%$ worldwide in 2010 (2). Osteo-articular TB (OATB) accounts for $\sim 2-3 \%$ of all TB cases, and $\sim 35 \%$ of extra-pulmonary TB cases (3). TB of the spine is potentially the most damaging form of OATB and is responsible for $\sim 50 \%$ of OATB cases (3). Furthermore, spinal infection is hematogenous or postoperative (4).

The cytotoxic effects of certain antibiotics on intervertebral disc (IVD) cells were investigated in animals and humans $(5,6)$. The penetration and distribution of antibiotics into avascular IVDs is significantly dependent on the charge of the antibiotics (7). The concentration of cephazolin, a drug administered intravenously during spinal surgery, reached a maximum concentration in the serum in $<10 \mathrm{~min}$, and in the IVDs it reached a concentration 15 times lower than that in the serum in $<60 \mathrm{~min}(8)$. Although studies have been conducted concerning the serum concentrations of anti-TB drugs, there are no studies that describe the penetration of these drugs into IVDs.

Liver injury, skin reactions, gastrointestinal and neurological disorders have frequently been observed as adverse effects of anti-TB treatment (9). Hepatotoxicity has been identified to be a common adverse reaction to RIF, and peripheral neuropathy affecting muscles, joints and limbs in anti-TB drug-treated patients has been linked to neurotoxicity (10). In addition, INH has been connected to an increased risk of developing hepatitis 
and INH has been demonstrated to compete with vitamin B6 in its action as a cofactor in the synthesis of synaptic neurotransmitters (11). In anti-TB treatment using ETH, optic neuritis and retrobulbar neuritis were common toxic effects as well as pruritus, joint pain, gastrointestinal problems and hepatotoxicity (12). Dose-related hepatotoxicity and gastrointestinal imbalance were also adverse effects resulting from treatment with PYR (11). As anti-TB drugs are also applied in the treatment of OATB, they are required to reach infected IVDs. The effect of anti-TB drugs on IVD cells, particularly nucleus pulposus (NP) cells, has not yet been observed in terms of cell viability, gene expression or glycosaminoglycans (GAGs) concentration.

There are clear morphological and physiological differences between articular cartilage and NP tissues, suggesting that there are differences in their cellular phenotypes; however, COL1A1, COL2A1, ACAN, SOX9 and TGFB1, the key marker genes, were observed in the two tissues. The extracellular matrix of the NP is $\leq 80 \%$ hydrated, as a result of large quantities of the aggregating proteoglycan, consisting of aggrecan protein encoded by $A C A N$. This proteoglycan is entangled in a variably orientated scaffold of type II collagen fibers encoded by COL2A1 (13). Sox 9 encoded by SOX9, is involved in chondrocyte differentiation and maintenance of the chondrocytic phenotype (14). Transforming growth factor $\beta 1$ (TGF- $\beta 1$, encoded by $T G F B 1$ ) is a member of the family of cytokines acting through the Smad protein pathway and regulates chondrogenesis (15). There have been no attempts to characterize the expression of these key chondrogenic genes in NP cells when treated with anti-TB drugs. Thus, this study aimed to demonstrate the impact of anti-TB drugs on IVDs as the incidence of tuberculosis is increasing in countries with AIDS epidemics (2), thus it is important to fully understand the effects of the anti-TB drugs.

NP cells were observed in the present study, as damage to this susceptible section of the IVDs by anti-TB drugs may be irreversible. In this study, by the incubation of human NP cells with INH, RIF, ETH and PYR, the following hypotheses were investigated: i) the expression of COL1A1, COL2A1, ACAN, $S O X 9$ and TGFB1 chondrocyte marker genes in NP cells may be sensitive to treatment with anti-TB drugs; and ii) the transcriptional activity of the genes encoding matrix protein in the cultured cells may monitor functional changes during anti-TB therapy. Additionally, anti-TB drugs may influence NP cell viability or GAG synthesis. This study aimed to determine whether anti-TB drugs resulted in adverse side effects in NP cells.

\section{Subjects and methods}

Subjects. Human NP cells were collected (using an anterior approach) from 12 patients undergoing treatment to correct thoraco-lumbar or lumbar scoliosis during the routine preparation of the site for anterior spodylodesis. All patients were treated in Poznań Medical University Hospital of Pediatric Orthopaedics and Traumatology and were recruited into the study consecutively.

The following eligibility criteria was adopted: i) 10-19 years of age; ii) adolescent idiopathic scoliosis (AIS); iii) a Cobb angle of $>40$ degrees; and iv) scoliosis correction from an anterior approach with routine removal of an IVD for preparation of the site for anterior spodylodesis. NP cells were extracted from non-degenerative IVDs.

Patients were excluded from the study if they had taken painkillers, antibiotics or steroids prior to hospital admission; had undergone previous surgery in the spinal area; or had exhibited indications of TB infection.

Patients who fulfilled the inclusion criteria received in-depth information concerning the aim of the study and were assured anonymity. Informed consent from the legal guardians of each patient was obtained prior to requesting permission from the patients to obtain the NP cells. The mean age of the patients was $16 \pm 2.3$ years (range, 14-19). The Ethics Committee of Poznań University of Medical Sciences (Poznań, Poland; approval no. 838/09) approved the design of this study and confirmed its accordance with universal ethical principles.

Cell culture. Non-degenerate IVD tissue was dissected predominantly from Th12 to L3 vertebrae (in one case lumbar tissue was dissected from L1 to L4) to separate the NP from the annulus fibrosus (AF) tissue. The NP was enzymatically digested overnight at $37^{\circ} \mathrm{C}$ with $0.02 \%$ collagenase type II (Sigma, St. Louis, MO, USA) in a serum-free medium containing an antibiotic antimycotic solution (100 units penicillin, $100 \mu \mathrm{g}$ streptomycin and $25 \mathrm{ng}$ amphotericin B per milliliter; Sigma). The digested tissue suspension was filtered through a sterile nylon fabric to remove the remaining tissue debris. Cells were centrifuged at $300 \mathrm{x}$ g for $5 \mathrm{~min}$, seeded onto a tissue culture flask and cultured at $37^{\circ} \mathrm{C}$ in $5 \% \mathrm{CO}_{2} / 95 \%$ air, in (1:1 v/v) Dulbecco's modified Eagle's medium/Nutrient F-12 Ham (DMEM/F-12; Sigma) supplemented with 10\% fetal bovine serum (FBS; Sigma) and an antibiotic antimycotic solution (Sigma). For gene expression experiments, 150,000 cells were placed in each well of 6-well plates; while for cell viability experiments, 25,000 cells were placed in each well of 24-well plates. The activity of caspase-3 and -7 was determined on 96-well plates with 5,000 cells/well. For GAG assays 200,000 cells were placed in each well of 6-well plates. The following concentrations of test substances were used: $2.5 \mathrm{ng} / \mathrm{ml}$ TGF- $\beta 1$ (Promega Corporation, Madison, WI, USA), $5 \mu \mathrm{g} / \mathrm{ml}$ INH, $10 \mu \mathrm{g} / \mathrm{ml}$ RIF, $2 \mu \mathrm{g} / \mathrm{ml}$ ETH and $5 \mu \mathrm{g} / \mathrm{ml}$ PYR (Sigma).

Gene expression. Following the 24-h incubation of NP cells with test substances, total RNA was extracted from the cultured cells using TRItidy $\mathrm{G}$, according to the manufacturer's instructions (Applichem GmbH, Darmstadt, Germany). Total RNA $(1 \mu \mathrm{g})$ was reverse-transcribed using the Superscript Reverse Transcriptase kit (Invitrogen Life Technologies, Carlsbad, CA, USA). Oligo(dT $)_{15}$-primed cDNAs were amplified by quantitative PCR (qPCR) using the primers listed in Table I and the Light Cycler FastStart DNA Master SYBR-Green I kit (Roche Diagnostics GmbH, Mannheim, Germany). Crossing-point values were calculated automatically, based on the second derivative algorithm, and the results were analyzed by the relative expression method. HMBS and MRPL19 were used as reference genes.

Cell viability and caspase activity. The 3-(4,5-dimethylthiazol-2-yl)-2,5-diphenyltetrazolium bromide (MTT)-based 
Table I. Primers used in qPCR.

\begin{tabular}{|c|c|c|c|}
\hline Gene & Primer sequence & Amplicon length (bp) & GenBank Accession nos \\
\hline$A C A N$ & $\begin{array}{l}\text { 5'-ACCAGACTGTCAGATACCCC-3' } \\
\text { 5'-CATAAAAGACCTCACCCTCC-3' }\end{array}$ & 156 & NM_001135 \\
\hline SOX9 & $\begin{array}{l}\text { 5'-GAAGAACGGGCAGGCGGA-3' } \\
\text { 5'-TTTGGGGGTGGTGGGTGG-3' }\end{array}$ & 181 & NM_000346 \\
\hline COL2Al & $\begin{array}{l}\text { 5'-ACCAGGACCAAAGGGACA-3' } \\
\text { 5'-GCAGCAAAGTTTCCACCA-3' }\end{array}$ & 246 & NM_033150 \\
\hline COL1A1 & $\begin{array}{l}\text { 5'-GAAGGGACACAGAGGTTTCAG-3' } \\
\text { 5'-TTCCACGAGCACCAGCAG-3' }\end{array}$ & 179 & NM_000088 \\
\hline$T G F B 1$ & $\begin{array}{l}\text { 5'-GAAACCCACAACGAAATC-3' } \\
\text { 5'-AATTTCCCCTCCACGGCT-3' }\end{array}$ & 300 & NM_000660 \\
\hline MRPL19 & $\begin{array}{l}\text { 5'-TCCAACCGCCGCCGAAAC-3' } \\
\text { 5'-AACACGAAGAATACTTCCAACA-3' }\end{array}$ & 197 & NM_014763.3 \\
\hline$H M B S$ (PBGD) & $\begin{array}{l}\text { 5'-CCCTGGAGAAGAATGAAGTG-3' } \\
\text { 5'-TCCCCGAATACTCCTGAA-3' }\end{array}$ & 254 & NM_000190 \\
\hline
\end{tabular}

Cell Growth Determination kit (Sigma) was used for cell viability analyses. Following 24, 48 or 192 h of stimulation with test substances, the cells in 24-well plates were incubated in serum-free DMEM/F-12 with the addition of MTT $(0.5 \mathrm{mg} / \mathrm{ml})$. Following incubation for $4 \mathrm{~h}$, the cell culture medium was removed and solvent was added (1 mM hydrochloric acid in isopropanol anhydride; POCH S.A., Gliwice, Poland). Following gentle mixing, analysis was performed using the Stat-Fax 2100 spectrophotometer (Awareness Technology Inc., Palm City, FL, USA) at a wavelength of $630 \mathrm{~nm}$ (background absorbance was measured at a wavelength of $405 \mathrm{~nm}$ ).

Caspase activity was analyzed by a Caspase-Glo 3/7 assay (Promega Corporation). Following cell stimulation, Caspase-Glo 3/7 Reagent was added (culture medium: Caspase Glo 3/7 reagent, 4:1) to cells in a 96-well plate. Subsequent to incubation for $1 \mathrm{~h}$, luminescence was measured in the TD20/20 luminometer (Turner Designs Inc., Sunnyvale, CA, USA).

GAG level in NP cells. NP cells were grown in culture media with the addition of the test substances and digested with papain after 192 h. Subsequently, Blyscan Sulfated Glycosaminoglycan assays (Biocolor Ltd., Carrickfergus, UK) were performed according to the manufacturer's instructions.

Statistical analysis. For qPCR data, crossing-point values were transformed into relative quantities by the instrument software (LightCycler Software 4.05; Roche Diagnostics GmbH). Gene specific standard curves were applied to calculate the relative levels of respective transcript upon $\mathrm{Cp}$ values. The mean values of the target-to-reference ratios from at least three independent experiments were presented as the mean \pm SEM. Controls were normalized to one.

P-values for all gene expressions were calculated and $\mathrm{P}<0.05$ was considered to indicate a statistically significant difference. Statistical analysis was performed on data transformed into $\log _{10}$ values with the use of MS Excel and
GraphPad InStat software (La Jolla, CA, USA) applying the Student Neuman-Keuls post hoc analysis of variance.

\section{Results}

Gene expression. Fig. 1 demonstrates that treatment of NP cells with $2.5 \mathrm{ng} / \mathrm{ml} \mathrm{TGF}-\beta 1$ for $24 \mathrm{~h}$ resulted in an $80 \%$ decrease in $A C A N$ mRNA levels $(\mathrm{P}=0.003)$; while $C O L 1 A 1$, COL2A1, SOX9 and TGFB1 mRNA levels were not significantly changed. The NP cells were treated with $5 \mu \mathrm{g} / \mathrm{ml} \mathrm{INH}$ for $24 \mathrm{~h}$, resulting in a 2.4-fold increase in COL2A1 mRNA levels $(\mathrm{P}=0.025)$ and a 3 -fold increase in $A C A N$ mRNA levels $(\mathrm{P}=0.045)$; while those of COL1A1, SOX9 and TGFB1 were not significantly affected. Treatment of NP cells with $10 \mu \mathrm{g} / \mathrm{ml}$ RIF for $24 \mathrm{~h}$ increased COL1A1 mRNA levels 2.2-fold $(\mathrm{P}=0.010)$ but did not result in changes in $C O L 2 A 1$, $A C A N, S O X 9$ and TGFB1 mRNA levels. Treatment of NP cells with $2 \mu \mathrm{g} / \mathrm{ml}$ ETH for $24 \mathrm{~h}$ did not change the COL1A1, COL2A1, ACAN, SOX9 and TGFB1 mRNA levels. Treatment of NP cells with $5 \mu \mathrm{g} / \mathrm{ml}$ PYR for 24 hours resulted in an 8.7-fold increase in SOX9 mRNA levels ( $\mathrm{P}=0.017)$. COL1A1, $C O L 2 A 1, A C A N$ and TGFB1 mRNA levels were not significantly changed by PYR.

Cell viability. NP cells were treated with $2.5 \mathrm{ng} / \mathrm{ml}$ TGF- $\beta 1$ and anti-TB drugs to determine whether these substances induced changes in the cell viability. Fig. 2 demonstrates that following $192 \mathrm{~h}$ of treatment with $2.5 \mathrm{ng} / \mathrm{ml}$, TGF- $\beta 1$ decreased the viability of NP cells by $30 \%$. The same length of treatment with $5 \mu \mathrm{g} / \mathrm{ml} \mathrm{INH} \mathrm{led} \mathrm{to} \mathrm{a} 15 \%$ decrease in the viability of NP cells. Treatment of NP cells with $10 \mu \mathrm{g} / \mathrm{ml}$ RIF for $192 \mathrm{~h}$ diminished cell viability by $>30 \%$. Treatment with ETH $(2 \mu \mathrm{g} / \mathrm{ml})$ for $24 \mathrm{~h}$ increased the viability of NP cells 1.3-fold; however, PYR did not significantly alter NP cell viability. The caspase- 3 and -7 activity assay did not demonstrate an increase in activity in cells treated by anti-TB drugs (data not shown). 

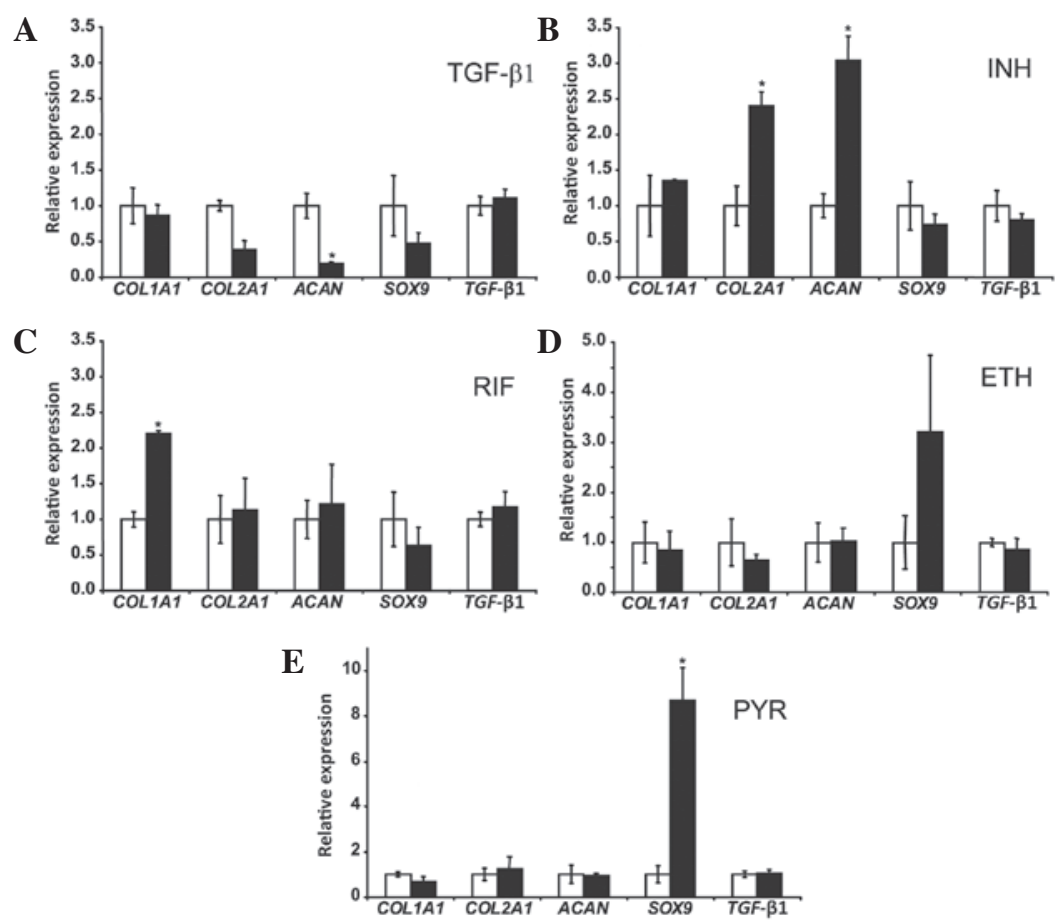

Figure 1. COL1A1, COL2A1, ACAN, SOX9 and TGF- $\beta 1 \mathrm{mRNA}$ levels in NP cells treated with (A) $2.5 \mathrm{ng} / \mathrm{ml} \mathrm{TGF}-\beta 1$ (B) $5 \mu \mathrm{g} / \mathrm{ml} \mathrm{INH} \mathrm{(C)} 10 \mu \mathrm{g} / \mathrm{ml}$ RIF (D) $2 \mu \mathrm{g} / \mathrm{ml} \mathrm{ETH}$ and (E) $5 \mu \mathrm{g} / \mathrm{ml}$ PYR for $24 \mathrm{~h}$ (black bars). Untreated control equals 1 (open bars). Error bars respresent \pm SEM. ${ }^{*} \mathrm{P}<0.05$. TGF- $\beta 1$, transforming growth factor- $\beta 1$; NP, nucleus polposus; INH, isoniazid; RIF, rifampicin; ETH, Ethambutol; PYR, pyrazinamide.

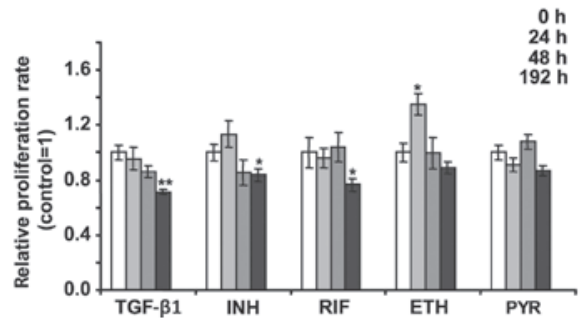

Figure 2. Viability test of NP cells treated 24,48 and $192 \mathrm{~h}$ with $2.5 \mathrm{ng} / \mathrm{ml}$ TGF- $\beta 1,5 \mu \mathrm{g} / \mathrm{ml} \mathrm{INH,} 10 \mu \mathrm{g} / \mathrm{ml} \mathrm{RIF,} 2 \mu \mathrm{g} / \mathrm{ml} \mathrm{ETH}$ and $5 \mu \mathrm{g} / \mathrm{ml}$ PYR. Untreated control equals 1 (open bars). Cells were grown in culture media with addition of test substances and an MTT assay was performed at the indicated time. Error bars represent $\pm \mathrm{SEM} .{ }^{*} \mathrm{P}<0.05$ and ${ }^{* *} \mathrm{P}<0.01$ $\mathrm{NP}$, nucleus polposus; TGF- $\beta 1$, transforming growth factor- $\beta 1$; INH, isoniazid; RIF, rifampicin; ETH, Ethambutol; PYR, pyrazinamide; MTT, 3-(4,5-dimethylthiazol-2-yl)-2,5-diphenyltetrazolium bromide.

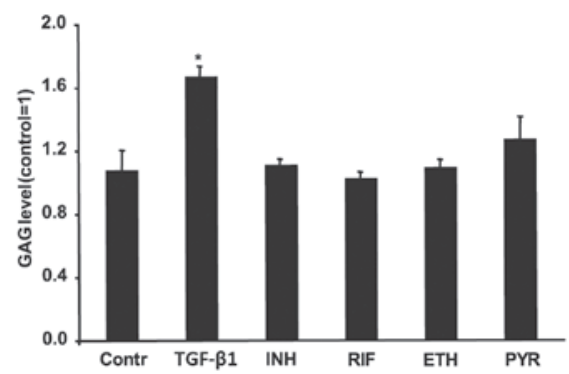

Figure 3. GAG level in NP cells. The NP cells were treated for $192 \mathrm{~h}$ with $2.5 \mathrm{ng} / \mathrm{ml} \mathrm{TGF}-\beta 1,5 \mu \mathrm{g} / \mathrm{ml} \mathrm{INH}, 10 \mu \mathrm{g} / \mathrm{ml} \mathrm{RIF,} 2 \mu \mathrm{g} / \mathrm{ml} \mathrm{ETH}$ and $5 \mu \mathrm{g} / \mathrm{ml}$ PYR. After $192 \mathrm{~h}$, the NP cells were digested with papain. Subsequently, a Sulfated Glycosaminoglycan assay was performed to analyze the GAG content. Data are shown as a fold of the untreated control value. Error bars represent \pm SEM. ${ }^{*} \mathrm{P}<0.05$. GAG, glycoseaminoglycan; NP, nucleus polposus; TGF- $\beta 1$, transforming growth factor- $\beta 1$; INH, isoniazid; RIF, rifampicin; ETH, Ethambutol; PYR, pyrazinamide.
GAG level in NP cells. NP cells were treated for $192 \mathrm{~h}$ with $2.5 \mathrm{ng} / \mathrm{ml}$ TGF- $\beta 1,5 \mu \mathrm{g} / \mathrm{ml}$ INH, $10 \mu \mathrm{g} / \mathrm{ml}$ RIF, $2 \mu \mathrm{g} / \mathrm{ml}$ ETH and $5 \mu \mathrm{g} / \mathrm{ml}$ PYR. A Sulfated Glycosaminoglycan assay (Blyscan) was subsequently performed. TGF- $\beta 1$ led to a 1.7-fold increase in GAGs production; however, treatment with anti-TB drugs did not result in a significant change in GAG content (Fig 3).

\section{Discussion}

The present study demonstrated the specific side effects of anti-TB drugs on human NP cell gene expression, viability and GAG synthesis. The toxicity of anti-TB drugs (INH, RIF, ETH and PYR) has been studied in hepatocytes and other types of cells, but no effects have been demonstrated in cells from the human articular system, particularly in human IVD cells. In the present study the side effects of the anti-TB drugs were divided into three categories: Stimulating chondrocyte marker genes and decreasing cell viability (INH and RIF), stimulating chondrocyte marker genes and non-regulating viability (PYR) and drug non-stimulating chondrocyte marker genes with observed viability effects (ETH).

Prior to investigating the impact of INH, RIF, ETH and PYR on NP cells, the identity of the cultured primary cells obtained during surgery was validated by the expression of the following chondrocyte marker genes: COL1A1, COL2A1, $S O X 9, A C A N$ and $T G F B 1$.In addition, TGF- $\beta 1$ was also used, as its impact on chondrocyte marker gene expression in NP cells has been determined previously (16). In the present study, the expression of ACAN in NP cells decreased with the addition of $2.5 \mathrm{ng} / \mathrm{ml}$ TGF- $\beta 1$, which was concordant with previous observations concerning the effect of $10 \mathrm{ng} / \mathrm{ml}$ TGF- $\beta 1$ on $A C A N$ 
expression in adolescent and adult NP cells (17). However, in similar conditions, in a previous study, $72 \mathrm{~h}$ of treatment with $10 \mathrm{ng} / \mathrm{ml}$ TGF- $\beta 1$ led to an increase in $A C A N$ expression and COL1A1, COL2A1 and SOX9 mRNA levels were constant (18). The presence of $1 \mathrm{ng} / \mathrm{ml} \mathrm{TGF}-\beta 1$ in platelet-rich plasma induced an increase in $A C A N, C O L 2 A 1$ and $S O X 9$ expression (15). Moreover, the effect of TGF- $\beta 1$ on NP cells was limited at $1 \mathrm{ng} / \mathrm{ml}$ and $2 \mathrm{ng} / \mathrm{ml}$, whereas concentrations of $\leq 1 \mathrm{ng} / \mathrm{ml}$ TGF- $\beta 1$ increased the viability of NP cells but a concentration of $\geq 2 \mathrm{ng} / \mathrm{ml}$ TGF- $\beta$ exhibited no effect (15). In the present study, TGF- $\beta 1$ led to a decrease in NP cell viability after $192 \mathrm{~h}$ and this antiproliferative effect of the growth factor confirms its involvement in cell growth. Although TGF- $\beta 1$ is an inhibitor of cell proliferation in the majority of cell types and has been shown to stimulate the growth of human nasal septal chondrocytes (19), it exhibited no visible effect on the growth of NP cells or stimulated NP cells $(18,20)$. It was hypothesized that TGF- $\beta 1$ requires a proportional quantity of other growth factors to be present in platelet-rich plasma to stimulate ACAN, COL2AI and SOX9 as well as promote cell viability. It appears that the effects of TGF- $\beta 1$ on chondrocytes are dependent upon the culture system to which it is added; therefore results may differ between studies (18).

To determine whether apoptosis may be responsible for the TGF- $\beta 1$ effect, the activity of caspase- 3 and -7 were analyzed. Caspases-3 and -7 belong to the group of caspases termed executioner caspases and exist within the cytosol as inactive zymogen dimers that are activated by initiator caspases- 8 and -9 (21). As no changes were observed in the caspase-3 and -7 activity it was concluded that apoptosis was not responsible for the decrease in NP cell viability in the presence of TGF- $\beta 1$ (data not shown).

Proteoglycan aggregates are commonly located in the structure of cartilage and IVDs. GAGs attach covalently to proteins, such as aggrecan, form proteoglycans. In the present study, similar to the study by Yang et al (17), the level of GAGs was increased by the addition of TGF- $\beta 1$ in NP cells. As TGF- $\beta 1$ induced a simultaneous decrease in the expression of the ACAN gene, it was concluded that the entire effect of TGF- $\beta 1$ on proteoglycan content in the extracellular matrix of NP remains unknown. This data implies that the proteoglycans, due to the action of TGF $\beta 1$, may contain less ACAN protein which is highly glycosylated (22). The present data are consistent with the observation that TGF- $\beta 1$, via Smad proteins, stimulates the expression of glucuronosyl transferase I (GlcAT-I), an important enzyme in the GAG biosynthesis pathway (23). Although NP cells from adolescents with idiopathic scoliosis may reveal some degenerative changes, we demonstrated that our NP cells were not degenerated as disc degeneration eliminates the regulation of GAGs synthesis by TGF- $\beta 1(17,23)$

NP cells that expressed marker genes have been used to investigate the effect of anti-TB drugs. The INH concentration in the plasma following oral administration of a 700-mg dose has been demonstrated to reach $3-5 \mu \mathrm{g} / \mathrm{ml}$ in $6 \mathrm{~h}$ (24). In the present study, NP cells were incubated with $5 \mu \mathrm{g} / \mathrm{ml} \mathrm{INH} \mathrm{for}$ $24 \mathrm{~h}$, resulting in increased $A C A N$ expression, which was the opposite effect to that of TGF- $\beta 1$. Moreover, INH stimulated $C O L 2 A 1$ gene expression, which may result in the biosynthesis of extracellular matrix. The mechanism of these anti-aging effects of INH remains to be elucidated, as it is not clear whether the drug itself, or its metabolites (such as hydrazine), act on $C O L 2 A 1$ and $A C A N$ gene expression (1). It has previously been suggested that the predominant toxic effect of INH is a result of its metabolites, monoacetyl hydrazine and hydrazine, as well as related compounds, which induce changes in the expression of numerous genes in the rat liver $(1,6,25,26)$. We suggest that a similar mechanism may be associated with the antiproliferative effect of INH on NP cells; however, this requires further investigation, as caspase- 3 and -7 were not activated (data not shown) and the synthesis of GAGs was not affected by treatment with INH.

In a study by Boman (27), the RIF concentration in the plasma decreased to $4 \mu \mathrm{g} / \mathrm{ml}$ in $6 \mathrm{~h}$ following oral administration of a $10-\mathrm{mg} / \mathrm{kg}$ dose, and the peak serum concentration was $8 \mathrm{~g} / \mathrm{ml}$. Similar to the results of the present study, RIF was previously observed to inhibit the growth of different types of cancer cells and osteoblast cells in vitro (28-30). The predominant elimination pathway is deacetylation into desacetyl rifampicin, while a 3 -formyl rifampicin is produced separately by hydrolysis $(20,28,29)$. RIF acts through the pregnane $\mathrm{X}$ receptor (PXR) and mediates the induction of the CYP2C9, CYP3A, CYP2 and MDR1 genes $(1,28,31)$. In the current study, RIF stimulated COL1A1 expression though a

typical PXR motif, TGAACT, is not present in the 1000bp located upstream of the transcription start site of COL1A1. Therefore, the mechanism of COLIAl regulation by RIF remains to be elucidated. In the NP cells of aged rabbits, COL1A1 was upregulated; thus, it was concluded that RIF may promote the aging of NP cells in patients treated with this drug (32). Observations of the antiproliferative effect of RIF on NP cells without a concomitant increase in caspase-3 and -7 activities requires additional investigation.

Following the administration of a single $25 \mathrm{mg} / \mathrm{kg}$ dose, the mean maximum concentration of ETH in serum has been demonstrated to reach $4.5 \mu \mathrm{g} / \mathrm{ml}$ (33-35). In the present study, of all the tested anti-TB drugs, ETH had the least effect on gene expression and was the only drug to stimulate cell viability after $24 \mathrm{~h}$. This anti-aging property of ETH subsequent to short-term incubation was not observed after $192 \mathrm{~h}$. The co-administration of therapeutic doses of ETH with other anti-TB drugs led to a marked decrease in male rat fertilizing capacity and fertility, and an increase in pre- and post-implantation embryo lethality (36). As the most serious potential adverse effect of ETH is ocular toxicity, manifested by optic or retrobulbar neuritis (7), the safety of ETH treatment in NP cells is required to be determined for longer therapeutic periods.

PYR achieved a maximum concentration of $49 \mu \mathrm{g} / \mathrm{ml}$ in the blood after $2 \mathrm{~h}$ (34). PYR is converted to pyrazinoic acid and further oxidized to 5-hydroxypyrazinoic acid by xanthine oxidase (37). Pyrazinoic acid inhibits translation in Mycobacterium tuberculosis; however, the mechanism of the influence of PYR on eukaryotic cells is not known (38). In this study, $5 \mu \mathrm{g} / \mathrm{ml}$ PYR induced the expression of SOX9, a transcription factor that is key in chondrogenesis (39). The same concentration of PYR did not affect cell viability, caspase-3 and -7 activity, and GAG synthesis. It was concluded that PYR exerted a moderate anti-aging effect on NP cells. PYR may be beneficial in IVD regeneration and may be used to prevent 
the loss of $S O X 9$ expression in degenerated IVD cells. It may also prevent a decrease in COL2AI and ACAN expression, as SOX9 is a common transcription factor for the genes $(14,40)$. Prolonged treatment with PYR is required to determine whether $C O L 2 A 1$ and $A C A N$ expression increases.

We propose that INH and PYR may have a dual role in anti-TB therapy; they decrease Mycobacterium levels, as well as stimulate the expression of genes encoding the extracellular matrix proteins (COL2A1 and $A C A N)$ and the SOX 9 protein. It was demonstrated that $192 \mathrm{~h}$ of treatment with INH or RIF resulted in cytotoxicity, indicated by a decrease in the number of NP cells. These results are similar to those obtained by Hoelscher et al (5) in annulus fibrosus cells, in which antibiotics (cefazolin and cefamandole) used in spinal surgery led to lower cell proliferation. The results, albeit on a small number of samples, suggested that the anti-TB drugs generated certain side effects on NP cells in vitro. To confirm these results, the collection of data following prolonged treatment with anti-TB drugs is required, as antimycobacterial therapy lasts for several months. Application of TGF- $\beta 1$ and anti-TB drugs revealed opposite effects on the expression of key chondrocyte genes and therefore should be investigated in combination. To the best of our knowledge, this is the first study to demonstrate that anti-TB drugs may be harmful to articular cells. The potential adverse effects of anti-TB drugs may be of importance to clinicians who use anti-TB drug for the routine chemotherapy of mycobacterial infections. In addition, the vertebral column of patients suffering pulmonary or extra-pulmonary mycobacterial infection, treated with INH, RIF, ETH or PYR, should be monitored periodically.

\section{Acknowledgements}

This study was supported by a Polish Ministry of Science and Higher Education grant (grant no. N N 403600538). The authors would like to thank to Ms. Beata Raczak and Ms. Bogumila Ratajczak for their help in the preparation of this paper.

\section{References}

1. Tostmann A, Boeree MJ, Aarnoutse RE, de Lange WC, van der Ven AJ and Dekhuijzen R: Antituberculosis drug-induced hepatotoxicity: concise up-to-date review. J Gastroenterol Hepatol 23: 192-202, 2008.

2. WHO: Global tuberculosis control http://www.who.int/tb/ publications/global_report/2011/gtbr11_main.pdf. Accessed October 9,2013.

3. Donald PR: The chemotherapy of osteo-articular tuberculosis with recommendations for treatment of children. J Infect 62: 411-439, 2011

4. Hadjipavlou AG, Mader JT, Necessary JT and Muffoletto AJ: Hematogenous pyogenic spinal infections and their surgical management. Spine (Phila Pa 1976) 25: 1668-1679, 2000.

5. Hoelscher GL, Gruber HE, Coldham G, Grigsby JH and Hanley EN Jr: Effects of very high antibiotic concentrations on human intervertebral disc cell proliferation, viability, and metabolism in vitro. Spine (Phila Pa 1976) 25: 1871-1877, 2000.

6. Schaberg T, Rebhan K and Lode H: Risk factors for side-effects of isoniazid, rifampin and pyrazinamide in patients hospitalized for pulmonary tuberculosis. Eur Respir J 9: 2026-2030, 1996.

7. Riley LH III, Banovac K, Martinez OV and Eismont FJ: Tissue distribution of antibiotics in the intervertebral disc. Spine (Phila Pa 1976) 19: 2619-2625, 1994.
8. Walters R, Moore R and Fraser R: Penetration of cephazolin in human lumbar intervertebral disc. Spine (Phila Pa 1976) 31: 567-570, 2006.

9. Black M, Mitchell JR, Zimmerman HJ, Ishak KG and Epler GR: Isoniazid-associated hepatitis in 114 patients. Gastroenterology 69: 289-302, 1975.

10. Aristoff PA, Garcia GA, Kirchhoff PD and Hollis Showalter HD: Rifamycins - obstacles and opportunities. Tuberculosis (Edinb) 90: 94-118, 2010.

11. Frydenberg AR and Graham SM: Toxicity of first-line drugs for treatment of tuberculosis in children: review. Trop Med Int Health 14: 1329-1337, 2009.

12. Griffith DE, Brown-Elliott BA, Shepherd S, McLarty J, Griffith L and Wallace RJ Jr: Ethambutol ocular toxicity in treatment regimens for Mycobacterium avium complex lung disease. Am J Respir Crit Care Med 172: 250-253, 2005.

13. Sive JI, Baird P, Jeziorsk M, Watkins A, Hoyland JA and Freemont AJ: Expression of chondrocyte markers by cells of normal and degenerate intervertebral discs. Mol Pathol 55: 91-97, 2002.

14. Gruber HE, Norton HJ, Ingram JA and Hanley EN Jr: The SOX9 transcription factor in the human disc: decreased immunolocalization with age and disc degeneration. Spine (Phila Pa 1976) 30: 625-630, 2005

15. Chen WH, Lo WC, Lee JJ, et al: Tissue-engineered intervertebral disc and chondrogenesis using human nucleus pulposus regulated through TGF-betal in platelet-rich plasma. J Cell Physiol 209: 744-754, 2006.

16. Freyria AM and Mallein-Gerin F: Chondrocytes or adult stem cells for cartilage repair: the indisputable role of growth factors. Injury 43: 259-265, 2012.

17. Yang SH, Lin CC, Hu MH, Shih TT, Sun YH and Lin FH: Influence of age-related degeneration on regenerative potential of human nucleus pulposus cells. J Orthop Res 28: 379-383, 2010.

18. Yang SH, Wu CC, Shih TT, Sun YH and Lin FH: In vitro study on interaction between human nucleus pulposus cells and mesenchymal stem cells through paracrine stimulation. Spine (Phila Pa 1976) 33: 1951-1957, 2008.

19. Bujía J, Sittinger M, Wilmes E and Hammer C: Effect of growth factors on cell proliferation by human nasal septal chondrocytes cultured in monolayer. Acta Otolaryngol 114: 539-543, 1994.

20. Zhang R, Ruan D and Zhang C: Effects of TGF-beta1 and IGF-1 on proliferation of human nucleus pulposus cells in medium with different serum concentrations. J Orthop Surg Res 1: 9 , 2006.

21. Boatright KM and Salvesen GS: Mechanisms of caspase activation. Curr Opin Cell Biol 15: 725-731, 2003.

22. Le Maitre CL, Pockert A,Buttle DJ, Freemont AJ and Hoyland JA: Matrix synthesis and degradation in human intervertebral disc degeneration. Biochem Soc Trans 35: 652-655, 2007.

23. Wu Q, Wang J, Skubutyte R, et al: SMAD3 controls $\beta$-1, 3-glucuronosyltransferase 1 expression in nucleus pulposus cells: implications of dysregulated expression in disc disease. Arthritis Rheum 64: 3324-3333, 2012.

24. Boxenbaum HG, Berkersky I, Mattaliano V and Kaplan SA: Plasma and salivary concentrations of isoniazid in man: preliminary findings in two slow acetylator subjects. J Pharmacokinet Biopharm 3: 443-456, 1975.

25. Klen $\varnothing$ TG, Kiehr B, Baunsgaard D and Sidelmann UG: Combination of 'omics' data to investigate the mechanism(s) of hydrazine-induced hepatotoxicity in rats and to identify potential biomarkers. Biomarkers 9: 116-138, 2004.

26. Knowles SR, Uetrecht J and Shear NH: Idiosyncratic drug reactions: the reactive metabolite syndromes. Lancet 356: 1587-1591, 2000.

27. Boman G: Serum concentration and half-life of rifampicin after simultaneous oral administration of aminosalicylic acid or isoniazid. Eur J Clin Pharmacol 7: 217-225, 1974.

28. Holdiness MR: Clinical pharmacokinetics of the antituberculosis drugs. Clin Pharmacokinet 9: 511-544, 1984.

29. Trnka L, Mison P and Staflova S: Interaction aspects of antimycobacterial drugs in the chemotherapy of tuberculosis. II. The role of rifampicin and other drugs in the dependent or independent action of drug associations in vitro. Chemotherapy 20: 82-91, 1974.

30. Westphal JF, Vetter D and Brogard JM: Hepatic side-effects of antibiotics. J Antimicrob Chemother 33: 387-401, 1994.

31. Zhuang W, Jia Z, Feng H, et al: The mechanism of the G0/G1 cell cycle phase arrest induced by activation of PXR in human cells. Biomed Pharmacother 65: 467-473, 2011. 
32. Clouet J, Pot-Vaucel M, Grimandi G, et al: Characterization of the age-dependent intervertebral disc changes in rabbit by correlation between MRI, histology and gene expression. BMC Musculoskelet Disord 12: 147, 2011.

33. Conte JE Jr, Golden JA, Kipps J, Lin ET and Zurlinden E: Effects of AIDS and gender on steady-state plasma and intrapulmonary ethambutol concentrations. Antimicrob Agents Chemother 45: 2891-2896, 2001

34. McIlleron H, Wash P, Burger A, Norman J, Folb PI and Smith P: Determinants of rifampin, isoniazid, pyrazinamide, and ethambutol pharmacokinetics in a cohort of tuberculosis patients. Antimicrob Agents Chemother 50: 1170-1177, 2006.

35. Peloquin CA, Bulpitt AE, Jaresko GS, Jelliffe RW, Childs JM and Nix DE: Pharmacokinetics of ethambutol under fasting conditions, with food, and with antacids. Antimicrob Agents Chemother 43: 568-572, 1999.
36. Shayakhmetova GM, Bondarenko LB and Kovalenko VM: Damage of testicular cell macromolecules and reproductive capacity of male rats following co-administration of ethambutol, rifampicin, isoniazid and pyrazinamide. Interdiscip Toxicol 5: 9-14, 2012.

37. Ellard GA and Haslam RM: Observations on the reduction of the renal elimination of urate in man caused by the administration of pyrazinamide. Tubercle 57: 97-103, 1976.

38. Shi W, Zhang X, Jiang X, et al: Pyrazinamide inhibits trans-translation in Mycobacterium tuberculosis. Science 333: 1630-1632, 2011.

39. Watts HG and Lifeso RM: Tuberculosis of bones and joints. J Bone Joint Surg Am 78: 288-298, 1996.

40. Hu G, Codina M and Fisher S: Multiple enhancers associated with ACAN suggest highly redundant transcriptional regulation in cartilage. Matrix Biol 31, 328-337, 2012. 